\title{
JUDAS EvERETT*
}

\section{The Future of EU-Russian Relations: a Common European Home?}

\begin{abstract}
The Cold War was a confrontation dominated by dogmatic ideology; the rise of Gorbachev and his attempts to inject new thinking into the Soviet Union were critical in ending that standoff. Generally, Gorbachev was successful in the field of foreign policy and many of his ideas and actions created lasting legacies which have shaped the world today. However, one idea which failed to gain much traction was his proposal regarding a Common European Home. The aim of this paper is to examine how this opportunity was missed or why hasn't it been taken advantage of, before moving on to analyse whether shared aims, freedoms, values and responsibilities exist between Russia and the EU today. Opinion polling shows that Russian values and opinions are complex, but often similar to other post-communist countries that have successfully become European Union member states. The issue of NATO expansion stands out as more problematic than a lack of shared values between the EU and Russian citizens.
\end{abstract}

Key words: Gorbachev, Common European Home, EU-Russian relations, values, opinion. JEL Classification: F50, F53, F55.

\section{Introduction}

The rise of Gorbachev and the end of the Cold War are often directly linked, especially in the area of lessening tensions between the USA and the USSR, whose confrontation had defined the Cold War period. Furthermore, releasing the countries

* National Research University Higher School of Economics, jeverett@hse.ru, judas.everett@gmail. com; ORCID: 0000-0003-0794-0153. 
brought into the Soviet Union's sphere of influence following the second world war would have been inconceivable under any previous leader, yet the Sinatra Doctrine did exactly that (Larrabee 1991). The improvement of relations between the USA and the USSR fostered by Gorbachev and Reagan had also led to several summits, meetings and ultimately the signing of the INF Treaty ${ }^{1}$ (Beschloss, Talbott, Little 1994). In the end, however, Gorbachev was more successful in internationally than domestically, although his concept of a Common European Home did not experience the same success as his bilateral negotiations with the US.

Following the Russian Soviet Federative Socialist Republic's declaration of sovereignty and disintegration of the USSR, Russian President Boris Yeltsin also showed a desire to find some kind of Common European Home. The political landscape had significantly changed by this point and Yeltsin showed enthusiasm for joining the European Union (Martin 1997). Although at no point during the Yeltsin presidency was Russia even close to being in a position to join the European Union, the prospect was positive in terms of signifying that the country was seeking to move closer to European norms and economic structuring. Since the rise of Vladimir Putin there had been considerable doubts raised over such a future for the Russian Federation, especially since Russian aggression in Crimea and Eastern Ukraine.

On the other hand, prior to this aggression, cooperation in certain areas, particularly economy; justice and home affairs; external security; research, education and culture (Benč et al. 2009) (Romanova, Zaslavskaya 2004), combined with a favourable view of the EU among Russian youth (DW 2013) suggested that this might have been subject to change in the future. Therefore, the questions here are: why did a Common European Home remain unrealised in the past? What are the future prospects for finding a Common European Home which includes Russia? And finally - to what extent the prospects regarding Russia can hope to contain the shared European values of human dignity, freedom, democracy, equality, the rule of law and respect for human rights?

The importance of soft power has been demonstrated (Nye 1990), as has the importance of soft power to the EU (Michalski 2005; Matlary 2006; Goldthau, Sitter 2015). Perhaps most important, however, is that due to 'its particular historical evolution, its hybrid polity, and its constitutional configuration, the EU has a normatively different basis for its relations with the world' (Manners 2002). In other words, the EU is not merely constructed on a normative basis, but it is predisposed

1 Treaty Between the United States of America and the Union of Soviet Socialist Republics on the Elimination of Their Intermediate-Range and Shorter-Range Missiles. 
to act in a normative way in world politics (Manners 2002). This has changed what is considered normal in world politics (Manners 2008), for this reason there is a need to consider aims, freedoms, values and responsibilities when discussing the EU.

\section{Unrealised Opportunities at the End of The Cold War?}

The Cold War had dominated international relations for over four decades and its end caught many by surprise. The stability of the situation was often noted as an unexpected positive side of the bipolar confrontation. As the confrontation came to an end many feared that chaos would ensue, that the international system would crumble and violence would rage. Even more were trapped in uncertainty, as the USSR, Yugoslavia and Czechoslovakia all disintegrated, some in more violent ways than the others. Gorbachev, the great hope for change, was successful in starting the reforms, but after being the victim of one of the most poorly planned and executed coups in history he fell into irrelevance, his career ended by the man who had blocked the coup's attempts to remove him - Boris Yeltsin. However, the fate of Yeltsin was not dissimilar to that of Gorbachev, beset by conservatives at home and increasingly unable to convince the West that investing money in the Russian Federation would not be a waste.

Even after the collapse of the USSR, suspicions remained. It was believed that Russia did not have the legal framework which could prevent the loss or stealing of funds, and that financial support may also allow their military industrial complex to continue to be supported (Nasar 1992). In the analysis of the period following the breakup of the Soviet Union, the enthusiasm of the time is replaced with a feeling that Russia has been somehow lost (see Conradi, McFoul, Lucas).

The rise of concern regarding Russia and whether it has been lost to the West for the immediate future is important - logically it implies that it had not always been so. Returning to the time when Gorbachev was rising to the highest position in the Soviet Union there was little sign that within just a few short years the Soviet Union would no longer exist and that the politics of the world would be irreversibly changed. Initially Reagan was not convinced by the new young leader of the USSR and as such made little effort to achieve bilateral co-operation or concrete goals in tandem with the Soviet Union. However, this had changed and Reagan's later declaration that his characterization of the USSR as the Evil Empire was no longer 
relevant was the clearest indication of this turnaround in the US-USSR relationship (Beschloss, Talbott, Little 1994).

The renunciation of the Brezhnev Doctrine was the clearest indication in the turnaround which had occurred in geopolitical reality. The stationing of hundreds of thousands of troops in East and Central Europe, followed by the violent repression and reversal of reforms in Hungary in 1956 and Czechoslovakia in 1968 had been central to the Soviet Union's geopolitical position. By renouncing such actions, in what was coined the Sinatra Doctrine, the way for reforms was cleared and even encouraged as reformers in Moscow were eager to use the Warsaw Pact countries as test subjects for their own reforms (Sebestyen 2010). However, many of the regimes in Warsaw Pact countries were significantly more conservative than Gorbachev's government, so clearing the way was one thing, but beyond suggesting reform Gorbachev was unwilling to act in any way which would contravene his stated intention to let these countries exercise self-determination over their futures.

It was not apparent how far the Sinatra Doctrine could be stretched. Clearly Gorbachev expected these countries to choose a form of socialism - perhaps one not dissimilar from Dubcek's socialism, which was crushed by Warsaw Pact forces in 1968 (Bialer 1988). However, would those countries be allowed greater sovereignty? Would they be allowed to pursue pure market capitalism? What of their relationship with western European communities? All of these questions were difficult to answer, especially as Gorbachev tried to balance the reformer and conservative factions within his country and his government. One thing was abundantly clear: NATO expansion was not to be accepted under any circumstances.

The good relationships which Gorbachev enjoyed with leaders in the western camp, as well as the adoration he received from foreign publics, suggested that a new settlement may be found in the East-West relations. It was in this context that his largely forgotten proposal of a Common European Home was made. At the time the proposal was noted to clash with traditional Soviet foreign policy thinking, as well as being greeted with some puzzlement and mistrust (Malcolm 1989). In his 1989 address to the Council of Europe in Strasbourg, Mikhail Gorbachev hailed the meeting as evidence of the fact that the pan-European process is a reality and the fact that it continues to evolve. He continued to state that:

'The Helsinki process has already commenced this important work of world-wide significance. Vienna and Stockholm brought it to fundamentally new frontiers. The documents adopted there are today's optimal expression of the political culture and moral traditions of European 
peoples. Now it is up to all of us, all the participants in the European process, to make the best possible use of the groundwork laid down through our common efforts. Our idea of a Common European Home serves the same purpose too.' (Mikhail Gorbachev 2015)

The speech was short on detail, Gorbachev admitted that he did not have notes in his pocket. However, military reductions and moving towards peace were stressed, as was the need to tighten both institutional connections across Europe and economic ties and the retention of the humanitarian aspect of the pan-European process. Furthermore, and more important for this paper's scope, a restructuring of the international order existing in Europe was suggested, one that would 'put the European common values in the forefront and make it possible to replace the traditional balance of forces with a balance of interests' (Mikhail Gorbachev 2015). In terms of security, a much greater role for the OSCE was envisaged. This is an idea which has endured in Russian foreign policy thinking much better than the Common European Home has managed to (Casier 2018).

The days of the Warsaw Pact and Comecon were clearly numbered as the results of the Round Table Agreements in Poland and subsequent free elections shook the communist world and changed the political landscape considerably. One by one, the communist regimes of the region fell. Events were spiraling out of control and it was becoming increasingly clear that the Soviet leaders were losing their grip on the situation. The achievements of co-operation were then thrown into doubt as the August coup was attempted in 1991. The US intelligence services had long known that a coup would be a likely result of the daring reforms which Gorbachev had embarked upon (Beschloss, Talbott, Little 1994), but the American response to the events was quite restrained, perhaps in order to protect their interests regardless of which faction prevailed (Beschloss, Talbott, Little 1994).

The same restraint was characteristic of how the Bush administration dealt with the increasing pre-eminence of Yeltsin and Gorbachev's loss of relevance. Hesitancy characterized the US's approach to developments in post-communist Europe. The idea of the USSR joining NATO was proposed by some, but joining an organization established to counter the Soviet Union itself, as well as its, now changing, ideology, was absolutely unthinkable. The idea was pure anathema even to reformers. Declassified documents have shown that officials lined up to give assurances against NATO expansion: Baker, Bush, Genscher, Kohl, Gates, Mitterrand, Thatcher, Hurd, Major and Woerner were among those who assured the Soviet leadership that NATO would not expand eastward (Savranskaya and Blanton 2017). As a compromise, in order to offer increased relations with NATO for those who sought membership and 
minimise the exclusion of those who did not (especially Russia), the Partnership for Peace (PfP) was proposed as a way to bring European countries together. According to President Clinton it was absolutely not intended to draw another line dividing Europe a few hundred miles to the east and was a track that would lead to NATO membership (Savranskaya, Blanton 2018).

The decision to expand NATO eastward, regardless of previous guarantees, was in part due to eagerness of some countries to join, e.g. Poland and the Baltic states, but also due to extensive lobbying from US arms contractors (Seelye 1998) and groups such as the U.S. Committee to Expand NATO, which was also led by the director of strategic planning for Lockheed Martin Corporation (Gerth and Weiner 1997). Ultimately, both EU and NATO expanded eastward, but only one of these made the vision of a Common European Home less likely - the expansion of NATO. Attempts to include Russia in NATO decision-making by creating a new body, the NATO-Russia Council, which replaced the NATO-Russia Permanent Joint Council that had been set up in 1997, failed to include Russia in NATO decisionmaking in any meaningful way. Former Bush adviser Thomas Graham explained that while the council was intended to include Russia in the decision-making processes, any issue which was important for the US government was actually worked out beforehand, so while Russia appeared to participate and be included, the reality was quite different (Conradi 2017). After several decades outside of the very institutions which Gorbachev was so desperate to see his country become a part of, the question is whether or not shared aims, freedoms, values and responsibilities exist which may allow this to become a reality in the future.

\section{Shared Aims, Freedoms, Values and Responsibilities Today?}

The fact that opportunities at the end of the Cold War may have remained unrealised does not mean that they can never be. However, as earlier discussed, for a Common European Home to become a reality, there must be shared aims, freedoms, values and responsibilities which exist today and would allow for such a realisation. The main values of the European Union are: human dignity, freedom, democracy, equality, the rule of law and respect for human rights (Europa.eu 2016). These are not values often associated with Russia in general, certainly the central government does little to promote them, but have they developed among citizens regardless? 
Even in some of the areas where Russia has been most famously at odds with the values espoused by the EU, there are signs of changing attitudes. For example, in a recent opinion poll conducted by the Levada Center, it was revealed that $47 \%$ of Russians support equal rights for gay people in general. A higher percentage (63\%) would accept an acquaintance's homosexuality (Interfax 2019). In the same year, the percentage of the populations which did not agree that gay, lesbian and bisexual people should have the same rights as heterosexuals across several postcommunist EU member states were as follows: Slovakia 59\%, Romania 54\%, Croatia $51 \%$, Hungary 46\%, Bulgaria 45\%, Poland 45\% (ILGA-Europe 2019). Therefore, while the situation is not ideal in many countries around Europe, it has not proven to be a barrier for cooperation or even EU member status. Moreover, it is notable that the opinion of homosexuality is improving in Russia and in the future it may prove to be even less of a barrier.

In terms of democracy the views of Russian citizens are, perhaps surprisingly, realistic, with by far the most common answer to a Levada Center poll stating that democracy exists in Russia only in part (Levada Center 2016). However, when asked what kind of democracy Russia should have only $16 \%$ chose a democracy like in another state (e.g. Europe or the USA), with 19\% selecting one like in the Soviet Union and $46 \%$ choosing something which corresponds to national traditions and the specifics of Russia (Levada Center 2016). In terms of what kind of state they would like Russia to become in the future, the most common answer (with 31\%) was that Russia should become a state with a market economy, a democratic system and respect for human rights similar to Western countries, but in a way corresponding to national traditions and specifics of Russia (Levada Center 2016). The need for a uniquely Russian way is a recurring theme in Russian opinion polling in general, regardless of whether that is due to the size, ethnic and social makeup of the country, or a mixture of all of the above.

The issue of whether or not Russia should join the EU is a more complicated one. Specific policy actions are more complex than general opinions or attitudes and, this being the case, relevant polling data should be viewed somewhat more skeptically. However, with that being said, before the matter of Crimea and the sanctions young Russians, in particular, had a positive attitude toward the EU (DW 2013), with 41\% in favour of joining the European Union sometime in the future, 19\% unsure and $40 \%$ against. This is a trend which EU member states seem eager to encourage, with the German politician Ronald Pofalla suggesting a visa-free regime for young Russians (DW 2019), a plan which the German FM pledged to discuss with other Schengen countries (Schengen Visa Info 2019). The Levada-Center (2017) found that 
only $4 \%$ stated that Russia should aim to become a member of the European Union, with $21 \%$ selecting "probably", $39 \%$ opting for "probably not" and $21 \%$ being firmly against while $15 \%$ remained unsure. In a country characterised by strong opinions, the uncertainty over the EU is interesting and suggests that, at least from the Russian public's point of view, the door to membership is certainly not closed, even if it is from the point of view of the EU and the government of the Russian Federation.

The European Union enjoys a fairly positive view from the Russian public in general. With $5 \%$ very positive, $45 \%$ mostly positive, $23 \%$ mostly negative, $11 \%$ very negative and $17 \%$ finding it difficult to say (Levada-Center 2019). This compares well with attitudes towards the USA ( $42 \%$ very positive and mostly positive), but is some way behind attitudes towards Germany (61\% very positive and mostly positive) (Levada-Center 2019). The issue of attitudes towards the EU and EU membership is complicated by the fact that the view of Russia itself is not entirely clear. A country of this size and variety is not simple even for its citizens to comprehend. As such, only $7 \%$ fully agree that Russia is a European country and 37\% somewhat agree, while $35 \%$ somewhat disagree, $13 \%$ fully disagree and $9 \%$ find it hard to say (LevadaCenter 2017).

The geopolitical reality is that Gorbachev's heady idea of a Common European Home, which was big on ideas but sparse on details, may be further away than ever. The lack of details, concrete action and insurmountable security concerns saw Gorbachev's Common European Home fail to materialise. Presently even beyond the geopolitical situation several issues still remain, such as the rule of law and respect for human rights. However, opinion polling suggests that, despite the actions of the Russian government, the views of the citizenry continue to develop in a direction similar to other post-communist states who became EU member states. If future Russian governments were to encourage such views, as well as respect for other human rights and the rule of law, then an increase in the speed of these changes is very much possible.

\section{Conclusions}

In conclusion, it seems that opportunities to better integrate Russia into Europe, and the West, have been missed. Russia retains agency and responsibility, especially for its aggressive actions, and the lack of more effort from the Russian side cannot be ignored, nor should it. However, as Brzeziński wrote in his (1994) Foreign Affairs article, the West and the US in particular lacked a well-considered and historically 
relevant successor to the grand strategy of the Cold War years. Such lack of strategy saw neither Russia finding its place in a Common European Home, nor increased security and trust in the region. In fact, the expansion of NATO was not well-thoughtout and the consequence was Russia's new leadership's inevitable distrust of the West. Although such feelings towards the European Union are lessening, the EU only has an interest in integrating states which share the same values.

Russian public opinion does not seem to be a major barrier in seeking membership of the EU, and despite popular opinion both parties are not without shared aims, freedoms, values and responsibilities. This is not to say that Russia could join the EU in the immediate future, but there are signs that the values and opinions of Russians do not constitute a significant barrier and may become even less so in the future. The biggest barrier to Russian integration into Europe, whatever form that may take, does not stem from the EU or any individual state, but from the expansion of NATO and Russian aggression against Ukraine, in particular. Whether any Russian politician could find a way to overcome what is viewed as deceit and betrayal to help steer Russia to a Common European Home is unclear, while Russian NATO membership certainly remains beyond the realm of reality, and attempts at co-operation were undermined by a lack of trust. Therefore, while the economic and social side of the Common European Home idea does have some potential, it is difficult to see how the national security side could be realised.

\section{References}

Benč V., Duleba A., 2009. Searching for New Momentum in EU-Russia Relations: Agenda, Tools and Institutions. Bratislava: Slovenská Spoločnost pre Zahraničnú Politiku, and Výskumné Centrum.

Beschloss M. R., Strobe T., 1994. At the Highest Levels: The inside Story of the End of the Cold War. Boston: Back Bay Books/Little, Brown and Company.

Bialer S. 1988. "Gorbachev's Program of Change: Sources, Significance, Prospects." Political Science Quarterly, Vol. 103, No. 3: 403. https://doi.org/10.2307/2150758.

Casier T. 2018. "Gorbachev's 'Common European Home' and its relevance for Russian foreign policy today." Debater a Europa, No. 18: 17-34. https://doi.org/10.14195/1647-6336_18_2.

Conradi P. 2017. Who Lost Russia? How the World Entered a New Cold War. London, England: Oneworld Publications Ltd. 
DW. 2013. "Russia: Young People in Particular Have a Positive Attitude toward the EU." May 7 , 2013. https://www.dw.com/en/russia-young-people-in-particular-have-a-positive-attitudetoward-the-eu/a-16931781 [accessed on: 11.10.2019].

DW. 2019. “Глава 'Петербургского диалога': Хотим добиться безвиза для молодых россиян.” DW.COM. July 16, 2019. https://bit.ly/2UhDpCr

Europa.eu. 2016. “The EU in Brief.” Text. European Union. June 16, 2016. https://europa.eu/ european-union/about-eu/eu-in-brief_en

Goldthau A. and Sitter N. 2015. "Soft Power with a Hard Edge: EU Policy Tools and Energy Security." Review of International Political Economy, Vol. 22, No. 5: 941-65.

Gorbachev M. 2015. "Address given by Mikhail Gorbachev to the Council of Europe (6 July 1989)." Text. CVCE.EU by UNI.LU. March 7, 2015. https://www.cvce.eu/en/obj/address_ given_by_mikhail_gorbachev_to_the_council_of_europe_6_july_1989-en-4c021687-98f94727-9e8b-836e0bclf6fb.html

ILGA-Europe. 2019. Annual Review of the Human Rights Situation of Lesbian, Gay, Bisexual, Trans and Intersex People in Europe 2019. Brussels: ILGA-Europe.

Interfax. 2019. “Треть россиян полностью оборвала бы общение со знакомым, узнав, что он гей.” Interfax.ru. Мay 23, 2019. https://www.interfax.ru/russia/662150 [accessed on 29.09.2019].

Larrabee F. S. 1991. "The New Soviet Approach to Europe." Proceedings of the Academy of Political Science, Vol. 38, No. 1: 1-25. https://doi.org/10.2307/1173809.

Levada Center. 2016. “Российская демократия.” January 14, 2016. https://www.levada. ru/2016/01/14/rossijskaya-demokratiya/ [accessed on: 29.09.2019].

Levada-Center. 2017. “Russia - EU.” September 26, 2017. https://www.levada.ru/en/2017/09/26/ russia-eu/

Levada Center. 2019. "Attitudes toward Countries." August 10, 2019. https://www.levada.ru/ en/2019/10/08/attitudes-toward-countries-2/ [accessed on: 1.10.2019].

Lucas E. 2014. The New Cold War: Putin's Threat to Russia and the West. St. Martin's Publishing Group.

Malcolm N. 1989. “The 'Common European Home' and Soviet European Policy.” International Affairs, Vol. 65, No. 4: 659-76. https://doi.org/10.2307/2622579.

Manners I. 2002. "Normative Power Europe: A Contradiction in Terms?" JCMS: Journal of Common Market Studies, Vol. 40, No. 2: 235-58.

Manners I. 2008. “The Normative Ethics of the European Union”. International Affairs, Vol. 84, No. 1: 45-60.

Martin S. 1997. "Beyond the G8, Yeltsin Sees His Country in the EU." The Irish Times. March 24, 1997. https://www.irishtimes.com/news/beyond-the-g8-yeltsin-sees-his-countryin-the-eu-1.55254 [accessed on: 13.10.2019]. 
Matlary J. H. 2006. "When Soft Power Turns Hard: Is an EU Strategic Culture Possible?" Security Dialogue, 37(1): 105-21.

McFaul M. 2018. From Cold War to Hot Peace: An American Ambassador in Putin's Russia. Boston: Houghton Mifflin Harcourt.

Michalski A. 2005. "The EU as a Soft Power: The Force of Persuasion", in: The New Public Diplomacy, 124-44. Springer.

Nasar S. 1992. "How to Aid Russians Is Debated." The New York Times, January 20, 1992, sec. Business. https://www.nytimes.com/1992/01/20/business/how-to-aid-russians-is-debated. html [accessed on: 13.10.2019].

Nye J. S. 1990. "Soft Power." Foreign Policy, No. 80: 153-71.

Romanova T., Zaslavskaya N. 2004. "EU-Russia: Towards the Four Spaces." Baltic Defence Review, Vol. 12, No. 2: 84-103.

Savranskaya S., Blanton T. 2018. "NATO Expansion: What Yeltsin Heard | National Security Archive." March 16, 2018. https://nsarchive.gwu.edu/briefing-book/russia-programs/ 201803-16/nato-expansion-what-yeltsin-heard\#_edn8

Schengen Visa Info. 2019. "German FM Says EU May Soon Consider Visa-Free Policy For Russians." Schengen Visa Info. July 26, 2019. https://www.schengenvisainfo.com/news/ german-fm-says-eu-may-soon-consider-visa-free-policy-for-russians/ [accessed on: 11.10.2019].

Sebestyen V. 2010. Revolution 1989: The Fall of the Soviet Empire. 1st Vintage books ed., New York: Pantheon Books. 